\title{
Stroke risk scores to predict hospitalization for acute decompensated heart failure in atrial fibrillation patients
}

\author{
ANDREEA CRISTINA IVĂNESCU ${ }^{1}$, GHEORGHE-ANDREI DAN ${ }^{1,2}$ \\ 1 "Carol Davila" University of Medicine and Pharmacy, \\ Bucharest, Romania \\ ${ }^{2}$ Cardiology Department, Colentina University Hospital, \\ Bucharest, Romania
}

\begin{abstract}
Introduction. Atrial fibrillation (AF) is the most frequent hospitalized arrhythmia. It associates increased risk of death, stroke and heart failure (HF). Stroke risk scores, especially $\mathrm{CHA}_{2} \mathrm{DS}_{2}$-VASc, have been applied also for populations with different diseases. There is, however, limited data focusing on the ability of these scores to predict HF decompensation.

Methods. We conducted a retrospective observational study on a cohort of 204 patients admitted for cardiovascular pathology to the Cardiology Ward of our tertiary University Hospital. We aimed to determine whether the stroke risk scores could predict hospitalisations for acute decompensated HF in AF patients.

Results. C-statistics for $\mathrm{CHADS}_{2}$ and $\mathrm{R}_{2} \mathrm{CHADS}_{2}$ showed a modest predictive ability for hospitalisation with decompensated $\mathrm{HF}\left(\mathrm{CHADS}_{2}\right.$ : AUC $0.631 \mathrm{p}=0.003 ; 95 \% \mathrm{CI} 0.560-0.697$. $\mathrm{R}_{2} \mathrm{CHADS}_{2}$ : AUC $0.619 ; 95 \%$ CI $0.548-0.686 ; \mathrm{p}=0.004$ ), a marginal correlation for $\mathrm{CHA}_{2} \mathrm{DS}_{2-}$ VASc (AUC $0.57295 \%$ CI $0.501-0.641$ with a $\mathrm{p}$ value of only 0.09 , while the other scores failed to show a correlation. A CHADS $2 \geq 2$ showed a $\mathrm{RR}=2.96, \mathrm{p}<0.0001$ for decompensated HF compared to a score $<2$. For $\mathrm{R}_{2} \mathrm{CHADS}_{2} \geq 2, \mathrm{RR}=2.41, \mathrm{p}=0.001$ compared to a score $<2$. For $\mathrm{CHA}_{2} \mathrm{DS}_{2}-$ $\mathrm{VASc} \geq 2 \mathrm{RR}=2.18 \mathrm{p}=0.1$, compared to $\mathrm{CHA}_{2} \mathrm{DS}_{2}-\mathrm{VASc}<2$. The correlation coefficients showed a weak correlation for $\mathrm{CHADS}_{2}(\mathrm{r}=0.216 ; \mathrm{p}=0.001)$ and even weaker for $\mathrm{R}_{2} \mathrm{CHADS}_{2}(\mathrm{r}=0.197$; $\mathrm{p}=0.0047$ and $\mathrm{CHA}_{2} \mathrm{DS}_{2}-\mathrm{VASc}(\mathrm{r}=0.14 ; \mathrm{p}=0.035)$.

Conclusions. Among AF patients, $\mathrm{CHADS}_{2}, \mathrm{CHA}_{2} \mathrm{DS}_{2}$-VASc and $\mathrm{R}_{2} \mathrm{CHADS}_{2}$ were associated with the risk of hospitalisation for decompensated HF while ABC and ATRIA failed to show an association. However, predictive accuracy was modest and the clinical utility for this outcome remains to be determined.
\end{abstract}

Key words: acute decompensated heart failure, atrial fibrillation, stroke risk scores.

\section{INTRODUCTION}

Atrial fibrillation (AF) is the most frequent persistent arrhythmia, affecting $2-3 \%$ of the global population $[1,2]$. The latest estimates show that there are 8.8 million AF patients in Europe [3]. It is a public health problem worldwide, with a constantly increasing prevalence and incidence [4-7]. AF is also the most common rhythm disorder for which patients are hospitalized, being responsible for approximately $33 \%$ of hospitalizations for arrhythmias [8]. $\mathrm{AF}$ associates increased risk of $\mathrm{HF}$, hospitalizations and death [9].

$\mathrm{HF}$ and $\mathrm{AF}$ have common risk factors and pathophysiology [10]. They can cause each other or cause exacerbation of the other one by complex mechanisms including structural remodeling, neurohormonal activation, LV dysfunction (tachycardiomyopathy).
Various risk models were developed over the past years aiming to stratify the thromboembolic risk in $\mathrm{AF}$ patients and to discriminate those that benefit from antithrombotic therapy. Currently, the most validated and widely used score is $\mathrm{CHA}_{2} \mathrm{DS}_{2}$ VASc [11].

Among the first studies to evaluate thromboembolic risk factors in AF were AFI (the Atrial Fibrillation Investigators) [12] and SPAF (Stroke prevention in atrial fibrillation clinical trial) [13]. $\mathrm{CHADS}_{2}$ score, with superior accuracy in stroke prediction was obtained combining the two previous scores [14]

In 2010, G. Lip et al. [11] developed the $\mathrm{CHA}_{2} \mathrm{DS}_{2}$-VASc score refining the $\mathrm{CHADS}_{2}$ score with so-called "risk modifying" factors. Unlike the previous score, $\mathrm{CHA}_{2} \mathrm{DS}_{2}$-VASc has the great advantage of identifying patients who are really at low risk of stroke and who most likely do not require antithrombotic medication. 
$\mathrm{R}_{2} \mathrm{CHADS}_{2}$ score was created by adding two points for a $\mathrm{ClCr}<60 \mathrm{ml} / \mathrm{min}$, to the already established $\mathrm{CHADS}_{2}$. The $\mathrm{R}_{2} \mathrm{CHADS}_{2}$ score was validated on the cohorts from the ROCKET-AF and ATRIA studies $[15,16]$.

ATRIA is one of the newest scores proposed to assess thromboembolic risk and was derived from the ATRIA cohort [17]. It was validated on the ATRIA-Cardiovascular Research Network (CVRN) cohort [18]. This score tried to evaluate severe thromboembolic events (Rankin $\geq 3$ at discharge or death in the first 30 days), the predictive value being higher for this category of patients than for those without thromboembolic events [18].

The $\mathrm{ABC}$ score contains only 4 variables: age (A), biomarkers (troponin and NT-proBNP) (B), history of stroke/TIA (C). It was developed using the cohort from the ARISTOTLE study (a highly selected cohort of anticoagulated AF patients) and was subsequently validated on a smaller cohort from the RE-LY study $[19,20]$.

$\mathrm{ABC}$ is the only score that uses biomarkers, which add important information about subclinical cardiovascular dysfunction and are associated with vascular vulnerability [21]. ABC includes the variables with the highest prognostic power in multivariate $\mathrm{COX}$ analysis.

Although $\mathrm{CHA}_{2} \mathrm{DS}_{2}$-VASc and $\mathrm{CHADS}{ }_{2}$ were originally designed to stratify the risk of stroke in AF patients, recently they have been applied in studies with populations of various other pathologies $[22,23]$. For the other stroke risk scores, there is limited data on their ability to predict hospitalisation for HF decompensation [24, 25].

Therefore, we aimed to determine whether the stroke scores could also predict decompensated $\mathrm{HF}$ in $\mathrm{AF}$ patients.

\section{MATERIAL AND METHODS}

We included 204 patients, aged 18 to 80 , with either previously diagnosed or new onset AF, that were admitted to the Cardiology Ward of the Colentina Clinical Hospital in 2015.

The inclusion and exclusion criteria are listed in Figure 1.

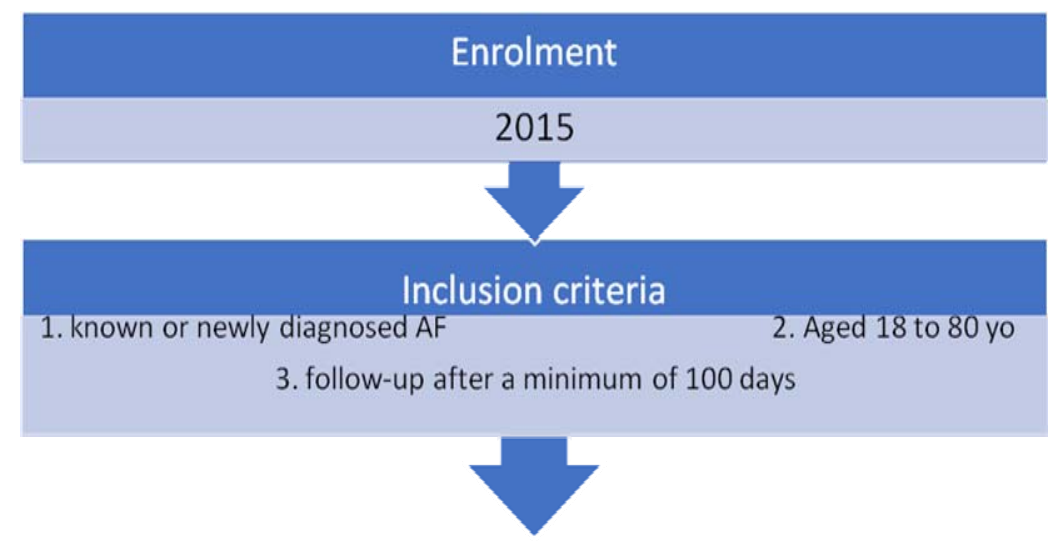

\section{Exclusion criteria}

1. Aged $<18$ yo or $>80$ yo

2. Pregnant or in the first 6 months postpartum

3. Known congenital heart disease $\quad 4$. unable to perform the follow-up

5. Inability to collect all the neededn data

Figure 1. Inclusion and exclusion criteria.

Although we screened a much higher number of patients, many of them were excluded for missing data. Being a retrospective analysis, we used data from patients charts or discharge summary. The most frequent causes for exclusion were missing parameters (needed for calculating all the risk scores included in our study) and lack of follow-up.
We calculated the following scores for each patient: $\mathrm{CHADS}_{2}, \mathrm{CHA}_{2} \mathrm{DS}_{2}$-VASc, $\mathrm{R}_{2} \mathrm{CHADS}_{2}$, ABC, ATRIA.

Patients were evaluated after a mean follow-up period of 365 days. The main outcome of interest was hospitalisation for acute decompensated $\mathrm{HF}$ after the index date. 
All patients signed a written consent for agreeing to participate in research activity with anonymized data. The research protocol was in accordance with the ethical guidelines of the Declaration of Helsinki.

\section{Statistical analysis}

Demographic and clinical characteristics at index evaluation are summarized using means \pm standard deviation for continuous variables and percentages for categorical variables.

The prediction ability of each scoring system was analysed with C-statistics and compared by the differences in the area under de curve (AUC) according to the ROC curve. We compared the AUCs for all scores using DeLong method.
The statistical analysis was performed using Microsoft Excel 16.34, SPSS Statistics 23 and MedCalc 19.2. The $\mathrm{p}$ value for statistical significance was set at $<0.05$.

\section{RESULTS}

The baseline characteristics of the study population are shown in Table 1 . The mean age at admission was 66 years old and the proportion of male patients was slightly smaller than that of women (46\% vs 54\%). 139 (68.1\%) patients were classified as having permanent AF while 23 (11.2\%) had persistent AF and 42 (20.5\%) paroxysmal AF.

Table 1

Baseline characteristics of the study population

\begin{tabular}{|c|c|c|c|c|c|}
\hline \multirow{2}{*}{\multicolumn{2}{|c|}{ Baseline characteristics }} & Total & $\begin{array}{c}\text { Patients with } \\
\text { hospitalisation for } \mathrm{HF}\end{array}$ & $\begin{array}{c}\text { Patients without } \\
\text { hospitalisation for HF }\end{array}$ & $P$ value \\
\hline & & $\mathrm{N}=204$ & $\mathrm{~N}=60$ & $\mathrm{~N}=144$ & \\
\hline \multicolumn{2}{|c|}{ Mean age (yr \pm SD) } & $\begin{array}{c}66 \\
( \pm 8.68)\end{array}$ & $\begin{array}{c}67 \\
( \pm 8.53)\end{array}$ & $\begin{array}{c}65 \\
( \pm 8.7) \\
\end{array}$ & 0.29 \\
\hline \multicolumn{2}{|c|}{ Gender (male) } & $\begin{array}{c}95 \\
(46 \%)\end{array}$ & $\begin{array}{c}29 \\
(48.3 \%)\end{array}$ & $\begin{array}{c}67 \\
(46.5 \%) \\
\end{array}$ & 0.93 \\
\hline \multirow{3}{*}{ AF type } & Paroxysmal & $\begin{array}{c}42 \\
(20.5 \%) \\
\end{array}$ & $\begin{array}{c}8 \\
(13.3 \%) \\
\end{array}$ & $\begin{array}{c}34 \\
(23 ., 6 \%) \\
\end{array}$ & 0.09 \\
\hline & Persistent & $\begin{array}{c}23 \\
(11.2 \%) \\
\end{array}$ & $\begin{array}{c}10 \\
(16.6 \%)\end{array}$ & $13(12,5 \%)$ & 0.11 \\
\hline & Permanent & $\begin{array}{c}139 \\
(68.1 \%) \\
\end{array}$ & $\begin{array}{c}42 \\
(70 \%) \\
\end{array}$ & $97(67,3 \%)$ & 0.71 \\
\hline \multicolumn{2}{|c|}{ HTN } & $\begin{array}{c}157 \\
(77 \%) \\
\end{array}$ & $\begin{array}{c}50 \\
(83.3 \%) \\
\end{array}$ & $\begin{array}{c}107 \\
(74.3 \%)\end{array}$ & 0.22 \\
\hline \multicolumn{2}{|c|}{$\mathrm{CHF}$} & $\begin{array}{c}56 \\
(27.5 \%) \\
\end{array}$ & $\begin{array}{c}32 \\
(53.3 \%) \\
\end{array}$ & $\begin{array}{c}24 \\
(16.6 \%) \\
\end{array}$ & $<0.0001$ \\
\hline \multicolumn{2}{|c|}{ Diabetes mellitus } & $\begin{array}{c}53 \\
(25 \%) \\
\end{array}$ & $\begin{array}{c}21 \\
(35 \%) \\
\end{array}$ & $\begin{array}{c}32 \\
(22.2 \%) \\
\end{array}$ & 0.08 \\
\hline \multicolumn{2}{|c|}{ Dyslipidaemia } & $\begin{array}{c}71 \\
(34.8 \%)\end{array}$ & $\begin{array}{c}18 \\
(30 \%)\end{array}$ & $\begin{array}{c}53 \\
(36.8 \%)\end{array}$ & 0.44 \\
\hline \multicolumn{2}{|c|}{ History of stroke/TIA } & $\begin{array}{c}18 \\
(8.8 \%) \\
\end{array}$ & $\begin{array}{c}3 \\
(5 \%) \\
\end{array}$ & $\begin{array}{c}15 \\
(10.4 \%) \\
\end{array}$ & 0.45 \\
\hline \multicolumn{2}{|c|}{ Coronary artery disease } & $\begin{array}{c}78 \\
(38.6 \%)\end{array}$ & $\begin{array}{c}29 \\
(48.3 \%)\end{array}$ & $\begin{array}{c}49 \\
(34 \%)\end{array}$ & 0.09 \\
\hline \multicolumn{2}{|c|}{$\mathrm{EF}( \pm \mathrm{SD})$} & $\begin{array}{l}45.8 \% \\
( \pm 11.6)\end{array}$ & $\begin{array}{c}40 \% \\
( \pm 12.9)\end{array}$ & $\begin{array}{c}48 \% \\
( \pm 10.2)\end{array}$ & 0.01 \\
\hline
\end{tabular}

Table 2 shows patients medication at index evaluation. 168 patients were anticoagulated, most of them with VKA $(137 ; 67.2 \%)$ and only 31 $(15.2 \%)$ NOAC. The remaining 36 (17.6\%) were not receiving oral anticoagulation.

Figure 2 and Tables 3-7 show the distribution of patients based on the values of the risk scores.

The AUC showed that $\mathrm{CHADS}_{2}$ and $\mathrm{R}_{2} \mathrm{CHADS}_{2}$ have a modest predictive ability for decompensated HF $\left(\mathrm{CHADS}_{2}\right.$ : AUC $0.63195 \%$ CI $0.560-0.697 ; \mathrm{p}=0.003 . \mathrm{R}_{2} \mathrm{CHADS}_{2}$ : AUC $0.619 ; 95 \%$ CI $0.548-0.686 ; \mathrm{p}=0.004$ ), while the other stroke risk scores failed to show a correlation (ABC: AUC 0.514; 95\% CI 0.426$0.601 ; \mathrm{p}=0.76$. ATRIA: AUC $0.53795 \% \mathrm{CI}$ $0.46-0.6 ; \mathrm{p}=0.37) . \mathrm{CHA}_{2} \mathrm{DS}_{2}-\mathrm{VASc}$ had a AUC of $0.572(95 \%$ CI $0.501-0.641)$ but with $p=0.09$ (Figure 3). 
Table 2

Medical therapy of the study population

\begin{tabular}{|c|c|c|c|c|c|}
\hline \multirow{2}{*}{\multicolumn{2}{|c|}{ Medication at index evaluation }} & Total & $\begin{array}{c}\text { Patients with } \\
\text { hospitalisation for } \mathrm{HF}\end{array}$ & $\begin{array}{c}\text { Patients without } \\
\text { hospitalisation for } \mathrm{HF}\end{array}$ & $P$ value \\
\hline & & $\mathrm{N}=204$ & $\mathrm{~N}=60$ & $\mathrm{~N}=144$ & \\
\hline \multicolumn{2}{|c|}{ Beta blockers } & $156(76.5 \%)$ & $40(66.7 \%)$ & $116(80.6 \%)$ & 0.0512 \\
\hline \multicolumn{2}{|c|}{ AEIs/sartans } & $154(75.5 \%)$ & $48(80 \%)$ & $106(73.6 \%)$ & 0.47 \\
\hline \multicolumn{2}{|c|}{ Digoxin } & $65(31.9 \%)$ & $27(45 \%)$ & $38(26.4 \%)$ & 0.0149 \\
\hline \multirow{3}{*}{ Antiarrhythmic } & Total & $21(10.3 \%)$ & $6(10 \%)$ & $155(10.4 \%)$ & 0.87 \\
\hline & Amiodarone & $19(9.31 \%)$ & $6(10 \%)$ & $13(9.02 \%)$ & 0.96 \\
\hline & Propafenone & $2(0.98 \%)$ & 0 & $2(1.38 \%)$ & 0.89 \\
\hline \multicolumn{2}{|c|}{ Loop diuretics } & $84(41.2 \%)$ & $35(58.3 \%)$ & $49(34 \%)$ & 0.022 \\
\hline \multirow{2}{*}{$\mathrm{OAC}$} & VKA & $137(67.2 \%)$ & $47(78.3 \%)$ & $90(62.5 \%)$ & \multirow{2}{*}{0.4} \\
\hline & NOAC & $31(15.2 \%)$ & $5(8.3 \%)$ & $26(18.1 \%)$ & \\
\hline \multicolumn{2}{|c|}{ No OAC } & $36(17.6 \%)$ & $8(13.3 \%)$ & $28(19.4 \%)$ & 0.4 \\
\hline \multirow{2}{*}{$\mathrm{Ca}$ ch. antagonists } & DHP & $23(11.3 \%)$ & $8(13.3 \%)$ & $15(10.4 \%)$ & 0.98 \\
\hline & Non DHP & $12(5.9 \%)$ & $4(6.7 \%)$ & $8(5.6 \%)$ & 0.72 \\
\hline Stati & & $128(62.7 \%)$ & $39(65 \%)$ & $89(61.8 \%)$ & 0.78 \\
\hline
\end{tabular}
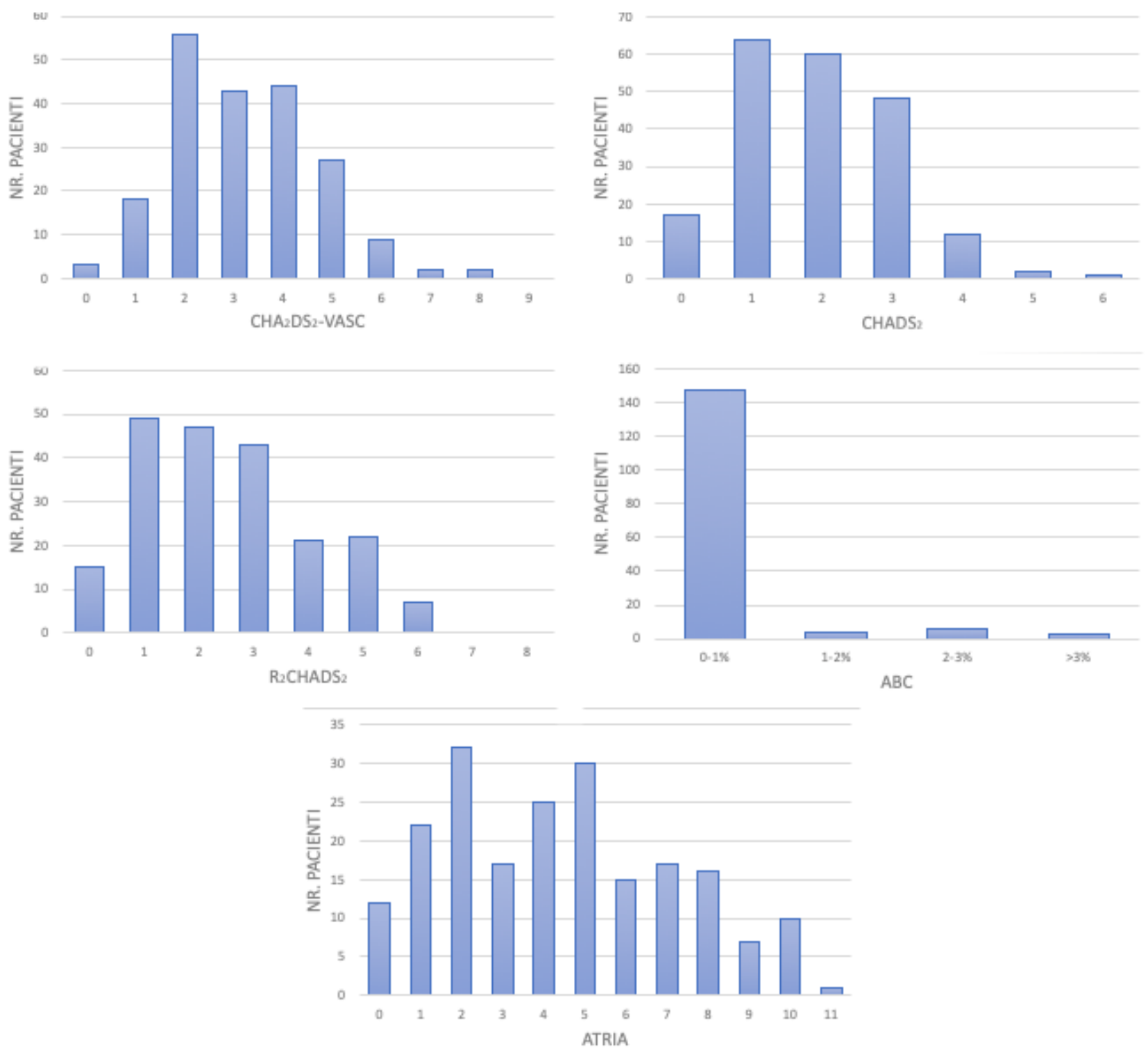

Figure 2. Frequency distribution of each score model. 
Table 3

Distribution of patients based on the $\mathrm{CHA}_{2} \mathrm{DS}_{2}$-VASc score

\begin{tabular}{cccc}
\hline & \multicolumn{3}{c}{$\mathbf{C H A}_{\mathbf{2}} \mathbf{D S}_{\mathbf{2}}$-VASc } \\
\cline { 2 - 4 } & $\begin{array}{c}\text { low risk (0 for males/ } \\
\mathbf{1} \text { for female) }\end{array}$ & $\begin{array}{c}\text { intermediate risk (1 for males/ } \\
\mathbf{2} \text { for females) }\end{array}$ & $\begin{array}{c}\text { high risk ( } \geq \mathbf{2} \text { for males/ } \\
\geq \mathbf{3} \text { for females) }\end{array}$ \\
\hline Without HF hospitalisation & $6(2.94 \%)$ & $33(16.17 \%)$ & $105(51.47 \%)$ \\
\hline With HF hospitalisation & 0 & $12(5.88 \%)$ & $48(23.50 \%)$ \\
\hline Total & $6(2.94 \%)$ & $45(22.05 \%)$ & $153(71.90 \%)$ \\
\hline
\end{tabular}

Table 4

Distribution of patients based on the $\mathrm{CHADS}_{2}$ score

\begin{tabular}{cccccccc}
\hline & \multicolumn{7}{c}{ CHADS $_{\mathbf{2}}$} \\
\cline { 2 - 7 } & $\mathbf{0}$ & $\mathbf{1}$ & $\mathbf{2}$ & $\mathbf{3}$ & $\mathbf{4}$ & $\mathbf{5}$ & $\mathbf{6}$ \\
\hline $\begin{array}{c}\text { Without HF } \\
\text { hospitalisation }\end{array}$ & $15(10.4 \%)$ & $51(35.4 \%)$ & $41(28.5 \%)$ & $28(19.4 \%)$ & $8(5.6 \%)$ & $1(0.7 \%)$ & $0(0 \%)$ \\
\hline $\begin{array}{c}\text { With HF } \\
\text { hospitalisation }\end{array}$ & $2(3.3 \%)$ & $13(21.7 \%)$ & $19(31.7 \%)$ & $20(33.3 \%)$ & $4(6.7 \%)$ & $1(1.7 \%)$ & $1(1.7 \%)$ \\
\hline Total & $17(8.3 \%)$ & $64(31.4 \%)$ & $60(29.4 \%)$ & $48(23.5 \%)$ & $12(5.9 \%)$ & $2(1 \%)$ & $1(0.5 \%)$ \\
\hline
\end{tabular}

Table 5

Distribution of patients based on the $\mathrm{R}_{2} \mathrm{CHADS}_{2}$ score

\begin{tabular}{cccccccccc}
\hline & \multicolumn{7}{c}{$\mathbf{R}_{\mathbf{2}} \mathbf{C H A D S}_{\mathbf{2}}$} \\
\cline { 2 - 9 } & $\mathbf{0}$ & $\mathbf{1}$ & $\mathbf{2}$ & $\mathbf{3}$ & $\mathbf{4}$ & $\mathbf{5}$ & $\mathbf{6}$ & $\mathbf{7}$ & $\mathbf{8}$ \\
\hline $\begin{array}{c}\text { Without HF } \\
\text { hospitalisation }\end{array}$ & $13(9 \%)$ & $39(27.1 \%)$ & $34(23.6 \%)$ & $27(18.8 \%)$ & $15(10.4 \%)$ & $14(9.7 \%)$ & $2(1.4 \%)$ & $0(0 \%)$ & $0(0 \%)$ \\
\hline $\begin{array}{c}\text { With HF } \\
\text { hospitalisation }\end{array}$ & $2(3.3 \%)$ & $10(16.7 \%)$ & $13(21.7 \%)$ & $16(26.7 \%)$ & $6(10 \%)$ & $8(13.3 \%)$ & $5(8.3 \%)$ & $0(0 \%)$ & $0(0 \%)$ \\
\hline Total & $15(7.4 \%)$ & $49(24 \%)$ & $47(23 \%)$ & $43(21.1 \%)$ & $21(10.3 \%)$ & $22(10.8 \%)$ & $7(3.4 \%)$ & $0(0 \%)$ & $0(0 \%)$ \\
\hline
\end{tabular}

Table 6

Distribution of patients based on the ATRIA score

\begin{tabular}{ccccccccccccc}
\hline & \multicolumn{10}{c}{ ATRIA } \\
\cline { 2 - 12 } & $\mathbf{0}$ & $\mathbf{1}$ & $\mathbf{2}$ & $\mathbf{3}$ & $\mathbf{4}$ & $\mathbf{5}$ & $\mathbf{6}$ & $\mathbf{7}$ & $\mathbf{8}$ & $\mathbf{9}$ & $\mathbf{1 0}$ & $\mathbf{1 1}$ \\
\hline $\begin{array}{c}\text { Without HF } \\
\text { hospitalisation }\end{array}$ & 11 & 17 & 24 & 8 & 18 & 19 & 10 & 12 & 12 & 6 & 6 & 1 \\
\hline $\begin{array}{c}\text { With HF } \\
\text { hospitalisation }\end{array}$ & $(1.7 \%)$ & $(11.8 \%)$ & $(16.7 \%)$ & $(5.6 \%)$ & $(12.5 \%)$ & $(13.2 \%)$ & $(6.9 \%)$ & $(8.3 \%)$ & $(8.3 \%)$ & $(4.2 \%)$ & $(4.2 \%)$ & $(0.7 \%)$ \\
\hline Total & 12 & 8 & 9 & 7 & 11 & 5 & 5 & 4 & 1 & 4 & 0 \\
& $(5.9 \%)$ & $(10.8 \%)$ & $(15.7 \%)$ & $(8.3 \%)$ & $(12.3 \%)$ & $(14.7 \%)$ & $(7.4 \%)$ & $(8.3 \%)$ & $(7.8 \%)$ & $(3.4 \%)$ & $(4.9 \%)$ & $(0.5 \%)$ \\
\hline
\end{tabular}

Table 7

Distribution of patients based on the $\mathrm{ABC}$ score

\begin{tabular}{ccccc}
\hline & \multicolumn{4}{c}{ ABC } \\
\cline { 2 - 5 } & $\mathbf{0 - 1 \%}$ & $\mathbf{1 - 2 \%}$ & $\mathbf{2 - 3 \%}$ & $>\mathbf{3 \%}$ \\
\hline Without HF hospitalisation & $107(74.3 \%)$ & $30(20.8 \%)$ & $5(3.47 \%)$ & $2(1.38 \%)$ \\
\hline With HF hospitalisation & $41(68.3 \%)$ & $17(28.3 \%)$ & $1(1.6 \%)$ & $1(1.6 \%)$ \\
\hline Total & $148(72.5 \%)$ & $47(23 \%)$ & $6(2.9 \%)$ & $3(1.47 \%)$ \\
\hline
\end{tabular}




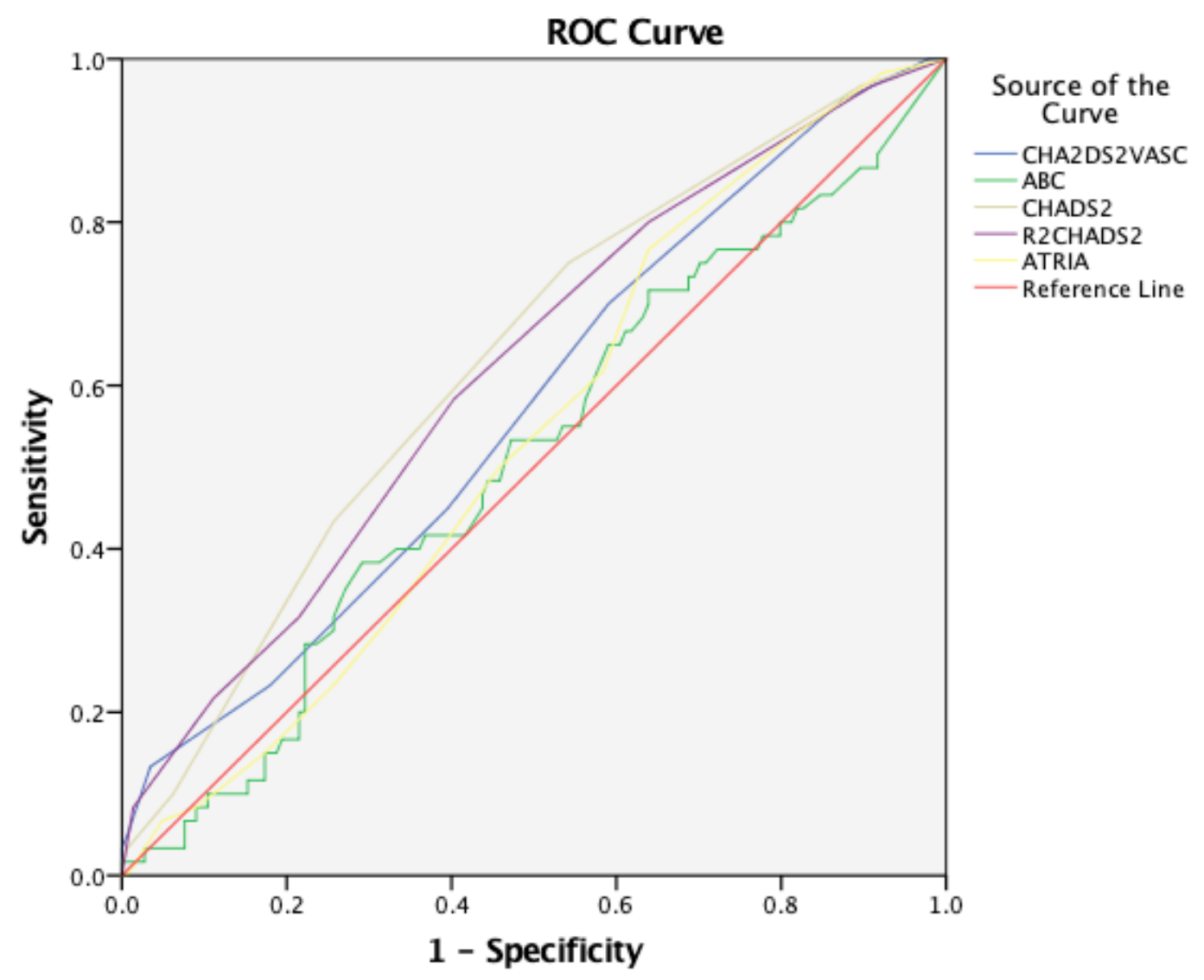

Diagonal segments are produced by ties.

Figure 3. Comparison of the ROC curves for the prediction of hospitalization for decompensated heart failure.

The values are relatively similar between scores, with the highest positive predictive values (PPV) for $\mathrm{R}_{2} \mathrm{CHADS}_{2}\left(37.6 \%\right.$ vs $36.5 \%\left(\mathrm{CHADS}_{2}\right)$ vs $33 \%\left(\mathrm{CHA}_{2} \mathrm{DS}_{2}-\mathrm{VASc}\right)$ and the highest negative predictive values (NPV) for $\mathrm{CHADS}_{2}(81.48 \%$ vs $76.6 \%\left(\mathrm{CHA}_{2} \mathrm{DS}_{2}-\mathrm{VASc}\right)$ vs $\left.77.45 \%\left(\mathrm{R}_{2} \mathrm{CHADS}_{2}\right)\right)$, the PPV are poor but with fairly good NPV, indicating that these scores could be useful in identifying patients at low risk for decompensated HF.

DeLong comparison of AUCs showed the following to be significantly different: $\mathrm{CHADS}_{2} \mathrm{vs}$ $\mathrm{CHA}_{2} \mathrm{DS}_{2}$-VASc $(\mathrm{p}=0.02), \mathrm{CHADS}_{2}$ vs ATRIA $(p=0.01), \mathrm{CHADS}_{2}$ vs ABC $(\mathrm{p}=0.02), \mathrm{R}_{2} \mathrm{CHADS}_{2}$ vs ATRIA $(p=0.03)$ and $\mathrm{R}_{2} \mathrm{CHADS}_{2}$ vs $\mathrm{ABC}$ $(\mathrm{p}=0.04)$.

The correlation coefficient showed a weak correlation for $\mathrm{CHADS}_{2}(\mathrm{r}=0.216 ; \mathrm{p}=0.001)$ and even weaker for $\mathrm{R}_{2} \mathrm{CHADS}_{2}(\mathrm{r}=0.197 ; \mathrm{p}=0.0047)$ and $\mathrm{CHA}_{2} \mathrm{DS}_{2}-\mathrm{VASc}(\mathrm{r}=0.14 ; \mathrm{p}=0.035)$.

Patients with a $\mathrm{CHADS}_{2} \geq 2$ had a relative risk (RR) of $2.96(95 \% \mathrm{CI} 1.80-4.87$; $<<0.0001)$ for decompensated HF when compared to a score $<2$. The RR for a $\mathrm{CHA}_{2} \mathrm{DS}_{2}-\mathrm{VASc} \geq 2$ is $2.18(95 \% \mathrm{CI}$ $0.74-6.35 ; \mathrm{p}=0.1$ ), compared to $\mathrm{CHA}_{2} \mathrm{DS}_{2}$-VASc
$<2$ and for $\mathrm{R}_{2} \mathrm{CHADS}_{2} \geq 2 \mathrm{RR}$ is $2.41(95 \% \mathrm{CI}$ 139-4.19; $\mathrm{p}=0.001)$ compared to a score $<2$.

On logistic regression, $\mathrm{CHADS}_{2}$ had an OR of 1.52 (95\% CI 1.15-2.01) $\mathrm{p}=0.002$ for predicting decompensated HF while for $\mathrm{CHA}_{2} \mathrm{DS}_{2}$-VASc the OR was 1.23 (95\% CI 1.01-1.51) $\mathrm{p}=0.03$ and for $\mathrm{R}_{2} \mathrm{CHADS}_{2}$ OR $1.31(95 \%$ CI 1.08-1.6) $\mathrm{p}=0.005$. In contrast, for $\mathrm{ABC}$ the OR was $1.03(95 \% \mathrm{CI}$ $0.63-1.69) \mathrm{p}=0.88$ and for ATRIA OR $1.03(95 \%$ CI $0.93-1.15) \mathrm{p}=0.47$.

There are competing conditions considered to be involved in the aetiology of decompensated HF. However, among components of $\mathrm{CHADS}_{2}$, and $\mathrm{CHA}_{2} \mathrm{DS}_{2}$-VASc, only congestive HF was found to be associated with decompensated HF (OR 2.29; 95\% CI 1.70-3.08; $\mathrm{p}<0.001$ ).

Among patients baseline characteristics, history of $\mathrm{HF}$ and ejection fraction were the only ones that showed a statistically significant difference between groups with and without hospitalisation for acute decompensated HF ( $p<0.0001$ for CHF. $p=0.01$ for $\mathrm{EF}$ ).

From patients medication, loop diuretic and digitalis were associated with the risk of hospitalisation 
for decompensated HF (furosemide: OR $2.71 ; 95 \%$ CI $1.46-5.03 ; \mathrm{p}=0.002$; digoxin: OR $2.28 ; 95 \%$ CI $1.21-4.28 ; \mathrm{p}=0.01)$. For these two classes of medication there was a significant difference between the groups with and without hospitalisation for HF ( $p=0.014$ for digoxin; $p=0.022$ for furosemide).

\section{DISCUSSIONS}

Stroke risk scores have been developed as combined schemes of the most important cardiovascular risk factors and comorbidities. Thus, the idea that they could also be used for different other estimations, is to some degree intuitive and it is worth pursuing.

Moreover, broadening the utility of a clinical tool that is already used for all AF patients is appealing because it allows the dispense of other time-consuming tools and it gives a better understanding of patient's risks and management strategy.

Simple and dynamic risk assessment should be implemented in clinical practice in order to detect high-risk patients.

Risk prediction for acute decompensated HF is especially important in $\mathrm{AF}$ patients since $\mathrm{AF}$ is highly associated with HF and also with an adverse prognosis in $\mathrm{HF}[25,26]$.

$\mathrm{HF}$ is a complex clinical syndrome that shares common risk factors and pathophysiology with $\mathrm{AF}$ [10].

In the Framingham study [27], in patients with $\mathrm{AF}$ and $\mathrm{HF}, 41 \%$ had HF first, $38 \%$ had AF first and in $21 \%$ both conditions occurred simultaneously.

Our study hypothesised that the stroke risk scores could predict acute decompensated HF is AF patients. It is a retrospective, small study which showed that the most widely used thromboembolic risk scores, $\mathrm{CHADS}_{2}$ and $\mathrm{CHADS}_{2}-\mathrm{VASc}$, as well as $\mathrm{R}_{2} \mathrm{CHADS}_{2}$, also correlate with hospitalisation for acute decompensated HF.

Although this correlation is modest, it opens the opportunity for future investigations.

Our results are consistent with previous studies that show a correlation for $\mathrm{CHADS}_{2}$ and $\mathrm{CHADS}_{2}-$ VASc with congestive HF [25] and all-cause cardiovascular hospitalisation [28].

Although the $\mathrm{ABC}$ stroke score is more complex and brings more information, our study failed to show an association with decompensated HF. This is in contradiction with recent evidence [29] that show significant higher ABC stroke scores for patients who had acute HF. Our results could be explained by the smaller cohort size with predominantly low-medium scores, and small number of events.

The $\mathrm{ABC}$ score has the disadvantage that the biomarkers predict different clinical events at the same time.

ATRIA stroke model brings supplementary information like glomerular filtration rate, and proteinuria. It also uses a broader range of age categories, which could potentially provide a better insight of the true risk. In the ATRIA study, it's discriminatory ability improved when outcome was restricted to severe events [18]. This is an important finding as preventing severe events is more important that preventing minor events and more relevant for patient's management.

For ATRIA, there is also some evidence [30] that in patients with $\mathrm{HFpEF}$, a score $\geq 8$ correlates with any hospitalisation as well as hospitalisation for HF.

This is also in contradiction with our findings that failed to show an association between ATRIA and acute decompensated HF A possible reason is that our outcome is not a major event, for which ATRIA showed it's best predictive ability. Also our cohort has a wide range of ejection fraction, with significant difference between the groups with and without decompensated HF.

In our study, independent predictors of decompensated HF were the ejection fraction and history of congestive HF. This suggests that history of $\mathrm{HF}$ is an important predictor of the recurrence of $\mathrm{HF}$ in $\mathrm{AF}$ patients, which is consistent with previous studies and reports [25].

From patients medication, loop diuretics and digitalis correlated with the risk of decompensated HF. Loop diuretics is the cornerstone of congestion management in chronic HF and the fact that it's use in outpatient medication prevents future events of decompensated HF is well known. The ESC Guidelines recommend loop diuretics to prevent hospitalization for decompensated HF in patients with congestion [31].

Although it has been previously reported that hypertension is a risk factor for congestive HF $[31,32]$, in our study there was no correlation.

The modest predictive ability demonstrated by our study and the differences from previously published data, confirm the need for future studies to better describe the potential benefit of using stroke risk scores for predicting acute decompensated HF as well as other outcome.

To this point, the well-known $\mathrm{CHADS}_{2}$ and $\mathrm{CHA}_{2} \mathrm{DS}_{2}$-VASc along with the derived $\mathrm{R}_{2} \mathrm{CHADS}_{2}$ 
remain the tools with the highest potential for extending their utility beyond their original purpose. The newer scores like the ABC and ATRIA, although more complex, seem not to bring any additional benefit for predicting decompensated HF.

\section{Study limitations}

The main limitation of this study is the small cohort size which also influences the number of events.

Another limitation is the retrospective nature of the study, observational data being obtained from patient's hospital chart after admission to Cardiology Department of a tertiary University
Hospital. Being a hospital-based study, one should note that patient's characteristics could differ from those of the general population.

\section{CONCLUSIONS}

$\mathrm{CHADS}_{2}, \mathrm{CHA}_{2} \mathrm{DS}_{2}$-VASc and $\mathrm{R}_{2} \mathrm{CHADS}_{2}$ have a modest ability to predict hospitalization for decompensated HF in AF patients, while ATRIA and $\mathrm{ABC}$ fail to show an association.

These scoring models could be useful in clinical practice to identify patients at increased risk for events but these results need further evaluation on larger and more heterogeneous cohorts.

Introducere. Fibrilația atrială $(F A)$ este cea mai frecventă aritmie care necesită spitalizare. Aceasta asociază un risc crescut de deces, accident vascular cerebral și insuficiență cardiacă (IC). Scorurile de risc pentru accident vascular cerebral (AVC), in special $\mathrm{CH}_{2} D S_{2}-V A S c$, au fost aplicate in populații cu patologii diverse. $\mathrm{Cu}$ toate acestea, există date limitate cu referire la capacitatea acestor scoruri de a prezice spitalizările pentru IC acut decompensată.

Metode. Am realizat un studiu observațional retrospectiv pe o cohortă de 204 de pacienți internați pentru patologie cardiovasculară la Secția de Cardiologie a Spitalului nostru Universitar terțiar. Am urmărit să determinăm dacă scorurile de risc pentru AVC ar putea prezice internările pentru IC acut decompensată la pacienții cu FA.

Rezultate. Valorile C-statistics pentru $\mathrm{CHADS}_{2}$ și $\mathrm{R}_{2} \mathrm{CHADS}_{2}$ au evidențiat o valoare predictivă modestă pentru spitalizare cu IC decompensată (CHADS $S_{2}: A U C$ 0,631 $p=0,003 ; 95 \%$ CI 0,560-0,697. R2 CHADS 2 : AUC 0,619; 95\% CI 0,5480,686; $p=0,004)$, o corelație marginală pentru $C H A_{2} D S_{2}-V A S c(A U C 0,57295 \%$ CI 0,501-0,641 cu o valoare $p$ de doar 0,09. ABC și ATRIA nu au evidențiat o corelație. Pentru CHADS $2 \geq 2 R R=2,96, p<0,0001$ pentru IC acut decompensată comparativ cu un scor $<2$. Pentru $R_{2} C_{H A D S} \geq 2, R R=2,41, p=0,001$ comparativ cu un scor $<2$. Pentru $\mathrm{CHA}_{2} D S_{2}-V A S c \geq 2 \mathrm{RR}=2,18 p=0,1$ comparativ cu $\mathrm{CHA}_{2} \mathrm{DS}_{2}-\mathrm{VASc}<2$. Coeficientul de corelație a arătat o asociere slabă pentru $\mathrm{CHADS}_{2}(r=0,216 ; p=0,001), \mathrm{R}_{2} \mathrm{CHADS}_{2}\left(r=0,197 ; \mathrm{p}=0,0047\right.$ și $\mathrm{CHA}_{2} \mathrm{DS}_{2^{-}}$ $\operatorname{VASc}(r=0,14 ; p=0,035)$.

Concluzii. $\mathrm{CHADS}_{2}, \mathrm{R}_{2} \mathrm{CHADS}_{2}$ și $\mathrm{CHA}_{2} D \mathrm{~S}_{2}$-VASc se asociază cu riscul de spitalizare pentru IC acut decompensată, în timp ce pentru ABC și ATRIA nu s-a evidențiat o asociere. $\mathrm{Cu}$ toate acestea, valoarea predictivă este modestă, iar utilitatea clinică pentru acest obiectiv necesită studii suplimentare.

Correspondence to: Andreea Cristina Ivănescu, M.D, Colentina Hospital, 19-21 Stefan Cel Mare Street, Postal code 020125, Bucharest, Romania

E-mail: andreea.cardio@gmail.com

Phone: +40751072606

Acknowledgements: none to declare

Conflict of interest disclosure: The authors declare that there are no conflicts of interest. 


\section{REFERENCES}

1. STEWART, S., HART, C.L., HOLE, D.J., MCMURRAY, J.J. Population prevalence, incidence, and predictors of atrial fibrillation in the Renfrew/Paisley study. Heart 2001 m.; 86(5):516-21.

2. KLOOSTERMAN, M., CRIJNS, H.J.G.M., VAN GELDER, I.C. Rising prevalence of atrial fibrillation in the elderly population: New challenges of geriatric cardiology. Europace 2019 m.; 21(10):1451-1453.

3. BENJAMIN, E.J., MUNTNER, P., AlONSO, A., BITTENCOURT, M.S., CALlAWAY, C.W., CARSON, A.P., et al. Heart Disease and Stroke Statistics-2019 Update: A Report From the American Heart Association,b.n.,B.m.,2019 m.

4. LIP, G.Y.H., BRECHIN, C.M., LANE, D.A. The global burden of atrial fibrillation and stroke: A systematic review of the epidemiology of atrial fibrillation in regions outside North America and Europe. Chest 2012 m.; 142(6):1489-1498.

5. BENJAMIN, E.J., WOLF, P.A., D’AGOSTINO, R.B., SILBERSHATZ, H., KANNEL, W.B., LEVY, D. Impact of atrial fibrillation on the risk of death: The Framingham Heart Study. Circulation 1998 m.; 98(10):946-952.

6. BALL, J., CARRINGTON, M.J., MCMURRAY, J.J. V, STEWART, S. Atrial fibrillation: Profile and burden of an evolving epidemic in the 21st century. Int. J. Cardiol. 2013 m.; 167(5):1807-1824.

7. CHUGH, S.S., HAVMOELlER, R., NARAYANAN, K., SINGH, D., RIENSTRA, M., BENJAMIN, E.J., et al. Worldwide epidemiology of atrial fibrillation: A global burden of disease 2010 study. Circulation 2014 m.;129(8):837-847.

8. DOUGLAS P. ZIPES, PETER LIBBY, ROBERT O. BONOW, DOUGLAS L. MANN, G.F.T.\& E.B. Braunwald's Heart Disease: A Textbook of Cardiovascular Medicine, Eleventh Edition,Elsevier,B.m.,2018 m.

9. STEWART, S., HART, C.L., HOLE, D.J., MCMURRAY, J.J.V. A population-based study of the long-term risks associated with atrial fibrillation: 20-Year follow-up of the Renfrew/Paisley study. Am. J. Med. 2002 m.; 113(5):359-364.

10. .KOTECHA, D., PICCINI, J.P. Atrial fibrillation in heart failure: What should we do?. Eur. Heart J. 2015 m.; 36(46):3250-3257.

11. LIP, G.Y.H., NIEUWLAAT, R., PISTERS, R., LANE, D.A., CRIJNS, H.J.G.M., ANDRESEN, D., et al. Refining clinical risk stratification for predicting stroke and thromboembolism in atrial fibrillation using a novel risk factor-based approach: The Euro Heart Survey on atrial fibrillation. Chest 2010 m.; 137(2):263-272.

12. Atrial Fibrillation investigators. Risk factors for stroke and efficacy of antithrombotic therapy in atrial fibrillation. Arch Intern Med. 1994 m.; 154:1449-1157

13. PREVENTION, S., INVESTIGATORS, F. Risk factors for thromboembolism during aspirin therapy in patients with atrial fibrillation: The stroke prevention in atrial fibrillation study. J. Stroke Cerebrovasc. Dis. 1995 m.;5(3):147-157.

14. GAGE, B.F., WATERMAN, A.D. Validation of Clinical Classification Schemes for Predicting Stroke Results From the National Registry of Atrial Fibrillation. JAMA J. Am. Med. Assoc. 2001 m.; 285(22):2864-2870.

15. PICCINI, J.P., STEVENS, S.R., CHANG, Y., SINGER, D.E., LOKHNYGINA, Y., GO, A.S., et al. Renal dysfunction as a predictor of stroke and systemic embolism in patients with nonvalvular atrial fibrillation: Validation of the R2CHADS2 index in the ROCKET AF. Circulation 2013 m.; 127(2):224-232.

16. FU, S., ZHOU, S., LUO, L., YE, P. Clinical Interventions in Aging Dovepress $r$ 2(gFr) ChADs 2 and r $2(g F r)$ ChA 2 Ds 2 VAsc schemes improved the performance of ChADs 2 and ChA 2 Ds 2 VASc scores in death risk stratification of Chinese older patients with atrial fibrillation. Clin. Interv. Aging 2017 m.; 12-1233.

17. FANG, M.C., GO, A.S., CHANG, Y., BOROWSKY, L., POMERNACKI, N.K., SINGER, D.E. Comparison of Risk Stratification Schemes to Predict Thromboembolism in People With Nonvalvular Atrial Fibrillation $2008 \mathrm{~m}$.

18. SINGER, D.E., CHANG, Y., BOROWSKY, L.H., FANG, M.C., POMERNACKI, N.K., UDALTSOVA, N., et al. A new risk scheme to predict ischemic stroke and other thromboembolism in atrial fibrillation: The ATRIA study stroke risk score. J. Am. Heart Assoc. 2013 m.; 2(3).

19. OLDGREN, J., HIJAZI, Z., LINDBÄCK, J., ALEXANDER, J.H., CONNOLLY, S.J., EIKELBOOM, J.W., et al. Performance and Validation of a Novel Biomarker-Based Stroke Risk Score for Atrial Fibrillation. Circulation 2016 m.; 134(22):1697-1707.

20. HIJAZI, Z., LINDBÄCK, J., ALEXANDER, J.H., HANNA, M., HELD, C., HYLEK, E.M., et al. The ABC (age, biomarkers, clinical history) stroke risk score: A biomarker-based risk score for predicting stroke in atrial fibrillation. Eur. Heart J. 2016 m.; 37(20):1582-1590.

21. HIJAZI, Z., OLDGREN, J., ANDERSSON, U., CONNOLLY, S.J., EZEKOWITZ, M.D., HOHNLOSER, S.H., et al. Importance of persistent elevation of cardiac biomarkers in atrial fibrillation: A RE-LY substudy. Heart 2014 m.; 100(15):1193-1200.

22. SIQUIN YE, MIN QIAN, BO ZHAO, R.B. et al. CHA2 DS2 -VASc Score and Adverse Outcomes in Patients with Heart Failure with Reduced Ejection Fraction and Sinus Rhythm. b.n.Available at: doi:10.1002/ejhf.613.

23. BIANCARI, F., ASIM MAHAR, M.A., KANGASNIEMI, O.P. CHADS2 and CHA2DS2-VASc scores for prediction of immediate and late stroke after coronary artery bypass graft surgery. J. Stroke Cerebrovasc. Dis. 2013 m.; 22(8):1304-1311.

24. PAOLETTI PERINI, A., BARTOLINI, S., PIERAGNOLI, P., RICCIARDI, G., PERROTTA, L., VALLEGGI, A., et al. CHADS2 and CHA2DS2-VASc scores to predict morbidity and mortality in heart failure patients candidates to cardiac resynchronization therapy. Europace 2014 m.; 16(1):71-80.

25. KOEDA, Y., KOMATSU, T., MATSUURA, Y., MORIOKA, H., UCHIMURA, Y., TAGUCHI, Y., et al. CHADS2 and modified CHA2DS2-VASc scores for the prediction of congestive heart failure in patients with nonvalvular atrial fibrillation. J. Arrhythmia 2017 m.; 33(5):488-493.

26. MAMAS, M.A., CALDWELL, J.C., CHACKO, S., GARRATT, C.J., FATH-ORDOUBADI, F., NEYSES, L. A meta-analysis of the prognostic significance of atrial fibrillation in chronic heart failure. Eur. J. Heart Fail. 2009 m.; 11(7):676-683.

27. WANG, T.J., LARSON, M.G., LEVY, D., VASAN, R.S., LEIP, E.P., WOLF, P.A., et al. Temporal relations of atrial fibrillation and congestive heart failure and their joint influence on mortality: The Framingham heart study. Circulation $2003 \mathrm{~m}$. ; 107(23):2920-2925. 
28. NACCARELLI, G.V., PANACCIO, M.P., CUMMINS, G., T.U., N. CHADS2 and CHA2DS2-VASc risk factors to predict first cardiovascular hospitalization among atrial fibrillation/atrial flutter patients. Am. J. Cardiol. 2012 m.;109(10):1526-1533.

29. CAMELO-CASTILlO, A., RIVERA-CARAVACA, J.M., MARÍN, F., VICENTE, V., LIP, G.Y.H., ROLDÁN, V. Predicting Adverse Events beyond Stroke and Bleeding with the ABC-Stroke and ABC-Bleeding Scores in Patients with Atrial Fibrillation: The Murcia AF Project. Thromb. Haemost. $2020 \mathrm{~m}$.

30. ZHU, W., WU, Y., ZHOU, Y., LIANG, W., XUE, R., WU, Z., et al. CHA2DS2-VASc and ATRIA Scores and Clinical Outcomes in Patients with Heart Failure with Preserved Ejection Fraction. Cardiovasc. Drugs Ther. $2020 \mathrm{~m}$.

31. FARIS, R.F., FLATHER, M., PURCELL, H., POOLE-WILSON, P.A., COATS, A.J.Diuretics for heart failure. John Wiley and Sons LtdAvailable at: doi:10.1002/14651858.CD003838.pub4.

32. SLIVNICK, J., LAMPERT, B.C. Hypertension and Heart Failure. Elsevier Inc.Available at: doi:10.1016/j.hfc.2019.06.007.

33. SORRENTINO, M.J.The Evolution from Hypertension to Heart Failure. Elsevier Inc.Available at: doi:10.1016/j.hfc.2019.06.005.

Received $15^{\text {th }}$ September 2020 